\title{
Implementasi Konsep Sustainable Architecture pada Desain Pusat Pelatihan Kerajinan Batu Gunung
}

\author{
Franadha Zaheza Agma ${ }^{1}$, Dian P.E. Laksmiyanti ${ }^{2}$, Failasuf Herman Hendra ${ }^{3}$ \\ 1,2,3 Jurusan Arsitektur, Fakultas Teknik Sipil dan Perencanaan, Institut Teknologi Adhi Tama Surabaya \\ Email: ${ }^{1}$ franadhazahezaa@ gmail.com
}

\begin{abstract}
Tulungagung belongs to one of mountainous area which is famous for the biggest producer of mountain stone craft in East Java. Unfortunately, no institution accommodates the activity of this industry. The craftsmen of andesite stone are dominated by the predecessors as the number of young generation who wants to continue this hereditary skill is very limited. On the one hand, an industrial sector is extremely vital to improve the macro economy of Indonesia. On the other hand, this sector also contributes a lot of carbon emissions. As the rate of energy use in Indonesia is classified as high, this condition triggers architects to design an industrial facility for maximizing the potentials of climate and area to reduce the rate of energy use. Therefore, this research aimed at designing a training centre for mountain stone craft to facilitate the craftsmen. For this reason, the researcher developed a design using qualitative analysis and empiric method. Several analyses were carried out concerning the area potentials such as local regulation, land order, site condition, contour, climate, as well as social and economic aspects of user candidates. All of them were summarized into the concept of design and then accomplished by implementing the concept in the working drawing. This research yielded a design of training centre for mountain stone craft in Tulungagung supported with facilities for training site as well as production and marketing. The design actualized the theme of Sustainable Architecture to optimize the natural and site potentials through integrated waste management.
\end{abstract}

Keywords: Sustainable Architecture, Training Centre, mountain stone craft.

\begin{abstract}
Abstrak. Tulungagung merupakan salah satu wilayah area pegunungan yang terkenal sebagai penghasil kerajinan batu gunung terbesar di Jawa Timur, namun tidak ada lembaga yang mewadahi kegiatan industri tersebut. Pengrajin batu andesit didominasi oleh para pewaris yang ahli dibidangnya karena semakin sedikit generasi muda yang meneruskan keahlian turun temurun ini. Sektor industry sangat diperlukan untuk meningkatkan ekonomi macro Negara Indonesia, di sisi lain sektor ini juga menyumbang cukup banyak emisi karbon. Laju penggunaan energi Indonesia tergolong tinggi sehingga hal ini menjadi tantangan tersendiri untuk Arsitek dalam mrancang sebuah fasilitas Industri bagaimana memaksimalkan potensi ikim dan kawasan guna menekan laju penggunaan energy. Penelitian ini bertujuan merancang pusat pelatihan kerajinan batu gunung sebagai wadah bagi pengrajin. Metode yang digunakan dalam riset ini adalah perancangan dengan analisa kualitatif dan metode desain, dimana dilakukan analisa terkait potensi kawasan seperti aturan daerah, tata guna lahan, kondisi site, kontur, iklim, aspek sosial dan ekonomi calon pengguna yang kemudian dirangkum menjadi sebuah konsep desain dan disesesaikan dengan implementasi konsep pada gambar kerja. Penelitian ini menghasilkan rancangan pusat pelatihan kerajinan batu gunung di tulungagung dengan fasilitas: tempat pelatihan, fasilitas produksi dan pemasaran. Desain ini mengusung tema Arsitektur Berkelanjutan untuk mengoptimalkan potensi alam dan site dengan manajemen limbah terpadu.
\end{abstract}

Kata Kunci: Arsitektur berkelanjutan, Pusat Pelatihan, Kerajinan Batu Gunung.

\section{Pendahuluan}

Banyaknya perpindahan penduduk dari desa kekota mengakibatkan besarnya kepadatan ruang disuatu daerah yang dapat bertambahnya tataguna lahan yang ada dikawasan tersebut. Daerah-daerah yang telah memiliki intensitas produktifitas yang tinggi maka para pendatang harusnya memiliki tempat dan hunian yang pasti, sehingga tidak menimbulkan kota yang kumuh dalam artian mendirikan bangunan tidak sesuai prosedur dan izin yang layak dan akan menimbulkan kerusakan pada lingkungan. Tahap perancangan kota harus terealisasi dan sesuai dengan rencana yang sesuai direncanakan dan 
dirancang dengan baik agar terwujud kota yang berkelanjutan secara merata dalam berbagai aspek kehidupan. (Amin, 2019). Pertumbuhan ekonomi sebuah kota hendaknya mengacu pada karakter kawasan dengan mengedepankan potensi yang ada di daerah tersebut baik ituu berupa potensi sumber daya alam maupun manusia. Pemanfaatan sumbedaya juga harus dilakukan secara bertanggung jawab sehingga terdapat proses berkelanjutan (sustainable development).

Selain untuk memaksimalkan potensi kawasan, pendekatan perancangan dengan metode climate responsive design juga dinilai dapat menekan konsumsi energy pada bangunan, baik itu energi operasional maupun embodied energy. Penerapan konsep ini dapat diimplementasikan pada perancangan tapak, konvigurasi massa, konvigurasi bentuk bangunan, perancangan façade, pemilihan material yang tepat, serta desain spasial dan interior yang sesuai dengan iklim dan aspek sosial masyarakat setempat (Laksmiyanti, et all, 2020). Menurut Baker \& Steemers (2005) desain yang tepat akan dapat menekan penggunaan energy hingga 2.5 kali lebih efektif.

Tulungagung merupakan daerah pegunungan dan menjadi bagian dari pegunungan wilis liman yang terkenal sebagai salah satu sentral indrustri kerajihan pahat yang dihasilkan dari batuan gunung tersebut. Jenis batuan yang dapat dimanfaatkan untuk kerajinan sekaligus menjadi kekayaan alam kawasan itu adalah batuuan Plutonik. Batuan beku plutonik berada di bawah kerak bumi dan berproses secara perlahan-lahan sehingga terjadi hablur yang mudah terlihat. Diorit, granit, dan gabro adalah batuan jenis vulkanik yang berasal dari lava pegunungan berapi yang terlempar kepermukaan bumi kemudian membeku sehingga memiliki permukaan yang halus. Batuan beku biasanya berwujud kokoh dan keras sehingga sering dimanfaatkan untuk batu nisan maupun bahan bangunan (Handayani, 2018). Batuan ini biasa digunakan sebagai kerajinan yang multi fungsi, yang biasanya digunakan untuk bahan dasar pembuatan ornamen patung dan alat kebutuhan rumah tangga seperti, cobek dan lumpang.

Penlitian ini bertujuan untuk mengimplementasikan konsep sustainable architecture pada desain Pusat Pelatihan Kerajinan Batu Gunung di Tulungagung sehingga rancangan yang diperoleh dapat mewadahi kegiatan dan kebutuhan masyarakat secara optimal, penggunaan energy secara efisien tanpa mengurangi kesempatan generasi mendatang untuk menikmati kekayaan alam warisan leluhur.

\section{Tinjauan Pustaka}

Pelatihan adalah proses dimana orang-orang mencapai kemampuan tertentu untuk membantu mencapai tujuan organisasi. Pengembangan kemampuan pada umumnya memiliki batas waktu yang singkat, jika berpengaruh pada kinerja yang dilakukan oleh perusahaan berhasil maka produktifitas yang dikembangkan oleh pekerja akan meningkat dengan sendirinya, Karyawan merupakan aset yang berharga bagi pengembang, tanpa seleksi yang tepat, kepuasan pelanggan dan kualitas produk bisa kurang optimal. Program pembelajaran yang efektif dapat membantu karyawan untuk mendapatkan kemajuan baru sesuai yang diinginkan. Dengan program tersebut juga mendapatkan kompetensi dan ketrampilan yang dibutuhkan dan untuk mengurangi kesalahan dalam bekerja (Dessler, 2005). Dalam kategori kerajinan berbahan keras, dibagi lagi menjadi dua material utama, yaitu alami dan buatan. Material yang terbentuk dari lingkungan adalah material yang dapat ditemukan di area hutan rindang dan perbukitan sekitar. Ciri utamanya adalah bentuknya terlihat kokoh. Contohnya bambu, kayu, dan rotan.

Sedangkan yang kedua adalah bahan buatan, material yang telah melalui proses tahap percetakan yang diproduksi sedemikian rupa sehingga tercipta bahan industri berupa logam, kaca plastik, besi baja dll. yang siap untuk dipasok dibeberapa daerah (Adian, 2019). Diadakannya pusat pelatihan yang melingkupi kerajinan batuan gunung ini berfungsi sebagai tempat untuk memfasilitasi para pekerja demi kenyamanan dan keamanan pada saat memproduksi kerajinan yang dibuat.

Kerajinan adalah terbentuknya suatu benda yang timbul bersama ide lalu merangkai dengan ketrampilan tangan . Umumnya, barang yang terbuat dari inspirasi tersebut banyak dikaitkan dengan unsur keindahan dan memiliki harga jual tinggi. Yang telah diproduksi secara besar dipasaran yaitu model jenis seni kriya. Produk massal tersebut dilakukan oleh para pembuat. Terdapat kelompokkelompok perajin sebagai home industry yang banyak berkembang di beberapa wilayah Indonesia. Hal ini sebagai bagian ekonomi kerakyatan. Oleh pemerintah pun digolongkan pada jenis Usaha Kecil Menengah (UKM) (Raharjo \& Suhartono, 2011). Metode pelaksanaan dari pengabdian kepada masyarakat ini menggunakan model pelatihan partisipatif dengan cara melakukan pendampingan 
pembuatan produk mulai dari pemilihan dan pembuatan desain yang diminati masyarakat serta memiliki kearifan lokal pada pembuatan produk, perlu pemahaman untuk penggunaan insektisida alami untuk jangka panjang bahan yang terbuat dari kayu sebelum pewarnaan, karena kualitas kayu yang beraneka ragam, serta bimbingan untuk sistem manajemen administrasi (Astuti, 2018).

\section{Metode Penelitian}

Jenis penelitian yang digunakan adalah penelitian deskriptif (Groat \& Wang, 2002), penelitian ini berkaitan dengan pengumpulan data untuk memberikan inspirasi pada waktu pengerjaan, umumnya dilakukan dengan metode survey, wawancara, pengamatan, studi kasus, studi korelasi, dan sebagainya. Dengan pengumpulan data untuk menggambarkan kinerja dilapangan. Adapun teknik metode yang dipakai untuk mendukung dalam penelitian.

Metodologi yang digunakan merupakan metodologi perencanaan dan perancangan pusat pelatihan. Metodologi sendiri, merupakan suatu cara pendekatan dan gambaran mengenai alur berpikir dalam memecahkan suatu permasalahan, sehingga dapat digambarkan dalam bentuk diagram. Metodologi bukan langkah-langkah penelitian, melainkan dasar bagi peneliti untuk menjalani langkahlangkah penelitian. Sehingga metode penelitian adalah salah satu faktor penting yang dapat membantu pelaksanaan perencanaan dan perancangan ini.

Diharapkan dari pembahasan ini akan mendapatkan sebuah alur berpikir yang jelas yang dijadikan dasar bagi peneliti untuk menjalani langkah-langkah penelitian dalam memecahkan permasalahan. data yang diperoleh dari observasi atau studi lapangan dan studi literatur dapat digunakan untuk pembahasan konsep arsitektur. Data tersebut diharapkan dapat memperkuat program perancangan. data spesifikasi lapangan baik kondisi-kondisi yang ada sebelum dan sekarang ini dapat disimpulkan, diambil dengan berbagai cara. Identifikasi bangunan sesuai dengan tema yang diambil. Programming merupakan tahapan penetapan masalah dalam perencanaan proses desain. Pra desain yang diuraikan dalam dokumen program berisi kondisi analisis existing dan usulan kondisi yang akan direncanakan sesuai dengan konsep awal, idea atau gagasan termasuk proses-proses pemecahan akan masalah tersebut.

Penerapan konsep arsitektur berkelanjutan yang menonjol terdapat pada bentuk desain yang mengedepankan fungsi dan tujuan untuk mempertahankan kearifan lokal yang ada pada suatu wilayah yang masih kental dengan kebudayaan dan cirikhas adat wilayah tersebut untuk masa mendatang. Paradigma "Form follow Function" atau bentuk mengikuti fungsi, pertama kali diperkenalkan oleh Louis Sullivan. Ia mengatakan bahwa bentuk tercipta karena ada fungsi yang menyertainya, di dalam teori tersebut berupa keberlangsungan yang terstruktur guna untuk kebutuhan ruang yang dibutuhkan. Fungsi merupakan bagian dari persepsi arsitektur moderen. (Maulida, 2016).

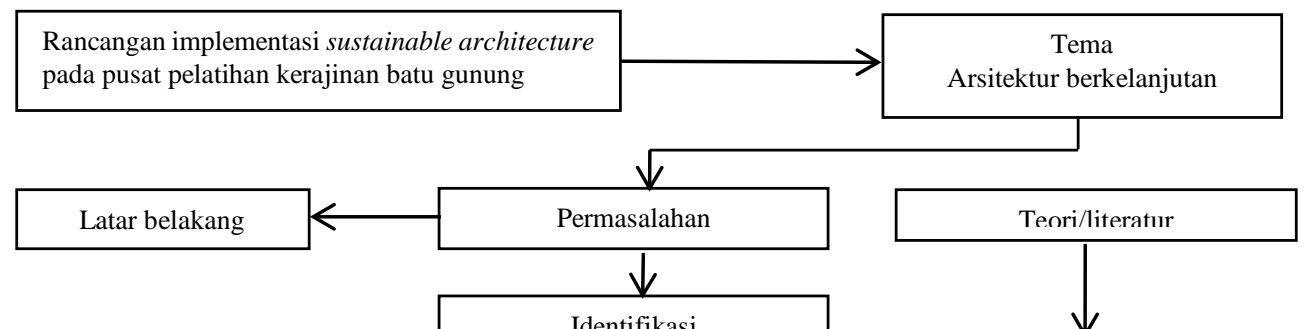




\section{Gambar 1. Diagram Alur Metodologi}

\section{Pembahasan}

Studi kasus literatur dilakukan dengan cara mengumpulkan data, melalui sumber yang telah diakui kejelasannya dengan membandingkan teknik pengumpulan data dengan cara studi lapangan, untuk melengkapi laporan, kebutuhan untuk mencari referensi pada studi literatur yang relefan memiliki dampak baik bagi penulis untuk menyusun laporan konsep. Data dapat dikumpulkan melalui jurnal ilmiah melalui website dan media internet. Obyek studi literatur yang akan dikaji yaitu cobek batu pak hari,Tulungagung dan cobek batu andan's oye, Magelang dan junaidi cobek dan lumpang, Salatiga dan cobek batu asli, Tulungagung.
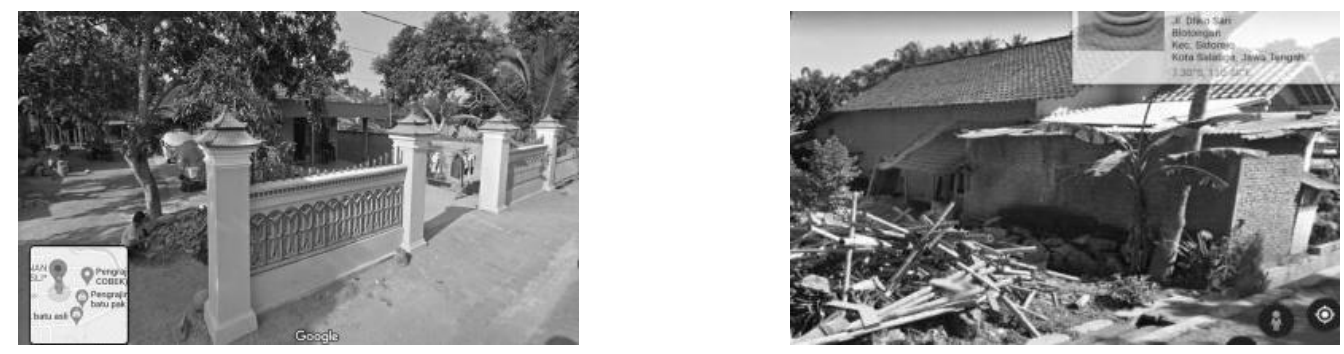

Gambar 2. (kiri) Studi Kasus Cobek Batu pak Hari;dan (kanan)Studi Kasus Andan's Oye

Setelah mengkaji studi literatur dapat disimpulkan bahwa terdapat beberapa kelebihan dan kekurangan dalam kebutuhan ruang tersebut sehingga dapat menjadi contoh dalam merancang.

\section{Tema}

Pemilihan desain bangunan bertema arsitektur berkelanjutan yang memenuhi kebutuhan saat ini, tanpa membahayakan kemampuan generasi mendatang, dalam memenuhi kebutuhan mereka sendiri. Dengan tema arsitektur berkelanjutan ini untuk memudahkan para pengguna bangunan untuk melanjutkan produktifitas untuk mengembangkan kearifan lokal yang berada disuatu wilayah dan akan berlanjut hingga masa mendatang.

\section{Makro Konsep "Ekologi"}


Ekologi memiliki arti sebagai suatu hubungan timbal balik antara makhluk hidup dan lingkungannya, dengan kata lain memperhatikan aspek-aspek seperti kesehatan manusia,pemanfaatan energi surya,serta penciptaan penghematan energi.

\section{Mikro Konsep Bentuk "Hemat Energi"}

Menciptakan rancangan yang dapat memaksimalkan energi alam serta memberikan penggunaan bahan material alam supaya rancangan akan terkesan lebih alami dan natural. dengan juga diciptakannya banyak bukaan sebagai sirkulasi alam ke dalam bangunan.

\section{Mikro Konsep Ruang "Natural Space”}

Dengan menciptakan ruang yang mampu menampilkan kesan alami dari alam yaitu dengan memberikan material-material menggunakan bahan batu marmer serta menciptakan sirkulasi yang dapat terarah serta teratur dengan cara memberikan aksen batuan gunung dibagian dinding lobby.

\section{Mikro Konsep Tata Lahan "Adaptif”}

Penataan lahan yang memperhatikan kondisi site dan sekitarnya, dengan tidak menghilangkan aspek vegetasi alami disekitarnya. Sangat baik bagi lingkungan sekitar dikarenakan unsur alami akan masih tetap terjaga.

\subsection{Program Ruang}

Penciptaan ruang dalam arsitektur dibutuhkan sebuah program rancangan awal sebelum melakukan pembangunan.Program akan memperlihatkan pola bentuk dan besaran ruang, untuk tempo durasi waktu serta pengguna yang termasuk dengan perlengkapan khusus atau kontrol pada lingkungan. Program tersebut secara implisit atau eksplisit membentuk suatu sirkulasi manusia,tatanan sosial dan organisasi. Hubungan tersebut dapat dinyatakan secara implisist melalui tahap syarat-syarat kedekatan dan harus secara eksplisist diuji oleh pengguna ruang. Melalui hubungan tersebut menjadi awal bagi hirarki yang akan digambarkan didalam bangunan,tahap ini harus memiliki kepastian untuk memenuhi fungsional dan kegunaan yang luar biasa agar dapat efektifitas yang diharapkan (Pujantara, 2014).

Aspek-aspek pemrograman ruang yang perlu diperhatikan adalah: kebutuhan ruang, besaran ruang, organisasi ruang, diagram ruang, dan persayaratan ruang.

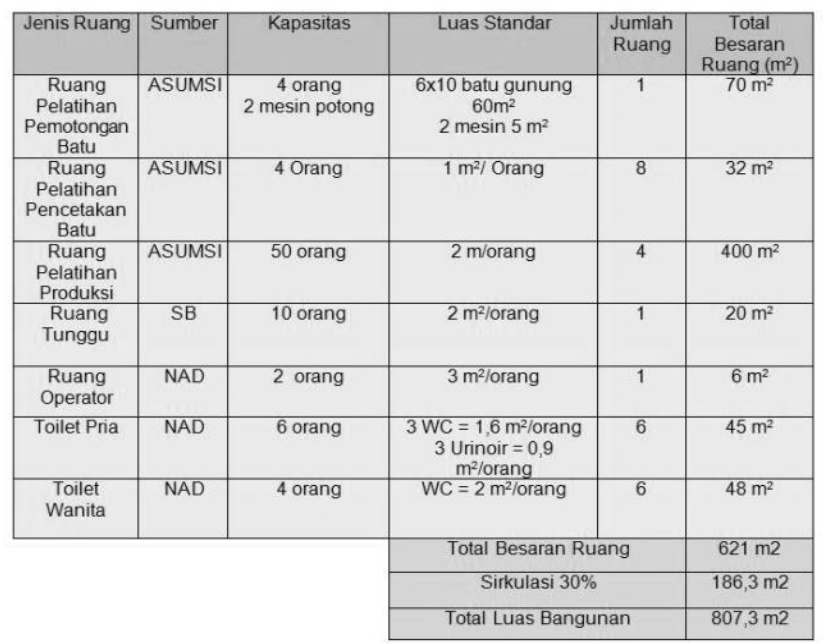

Gambar 3. Program Ruang Pelatihan Kerajinan Batu Gunung

\begin{tabular}{|c|c|c|c|c|c|}
\hline $\begin{array}{c}\text { Jenis } \\
\text { Ruang }\end{array}$ & Sumber & Kapasitas & Luas Standar & $\begin{array}{c}\text { Jumlah } \\
\text { Ruang }\end{array}$ & $\begin{array}{c}\text { Total } \\
\text { Besaran } \\
\text { Ruang }\left(\mathrm{m}^{2}\right)\end{array}$ \\
\hline $\begin{array}{c}\text { Ruang } \\
\text { Tamu }\end{array}$ & NAD & 5 orang & $25 \mathrm{~m}^{2}$ & 1 & $25 \mathrm{~m}^{2}$ \\
\hline $\begin{array}{c}\text { Ruang } \\
\text { Direktur }\end{array}$ & NAD & 1 orang & $20 \mathrm{~m}^{2} /$ orang & 1 & $20 \mathrm{~m}^{2}$ \\
\hline $\begin{array}{c}\text { Ruang } \\
\text { Kabag \& } \\
\begin{array}{c}\text { Staff } \\
\text { Administrasi }\end{array}\end{array}$ & TSS & 3 orang & $3 \mathrm{~m}^{2} /$ orang & 1 & $9 \mathrm{~m}^{2}$ \\
\hline $\begin{array}{c}\text { Ruang } \\
\text { Rapat }\end{array}$ & NAD & 15 orang & $2,5 \mathrm{~m}^{2} /$ orang & 1 & $38 \mathrm{~m}^{2}$ \\
\hline $\begin{array}{c}\text { Ruang } \\
\text { Arsip }\end{array}$ & TSS & 2 orang & $2,5 \mathrm{~m}^{2} /$ orang & 1 & $5 \mathrm{~m}^{2}$ \\
\hline
\end{tabular}




\section{Gambar 4. Program Ruang Staff Kerajinan Batu Gunung}

\subsection{Transformasi Bentuk}

Ide bentuk yang sederhana serta adanya bukaan-bukaan sebagai wujud hemat energi dan ramah lingkungan, bangunan ini akan menciptakan kesan nyaman bagi pengrajin serta adanya secondary skin. Bangunan ini juga akan dapat menerima cahaya serta udara dari luar supaya bisa masuk dengan baik, dengan begitu dapat menjadi bangunan yang dapat menyamankan penggunanya. Pada bagian kantor atau pengelola dan pamerannya akan diciptakan bentuk yang lebih modern semacam mall untuk dapat menarik masyarakat.

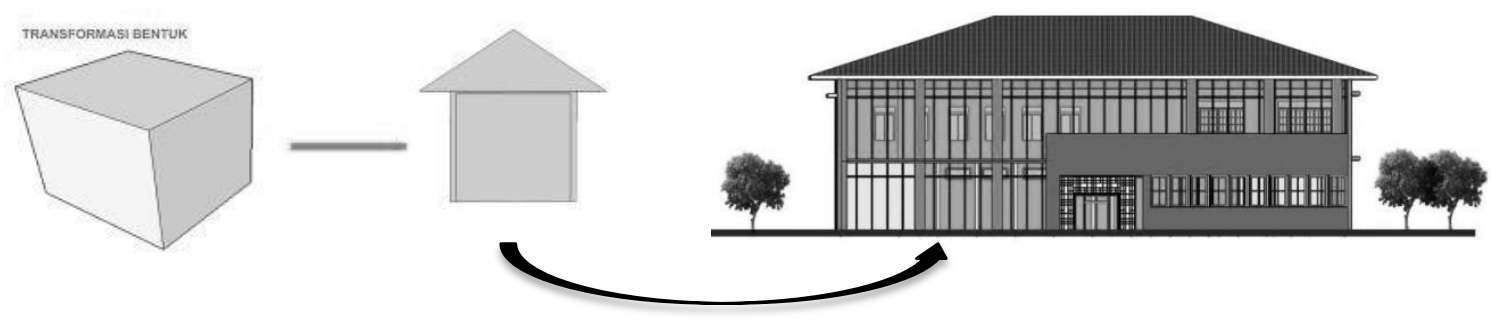

Gambar 5. Transformasi bentuk

\subsection{Transformasi Ruang}

Penciptaan ruangan yang menampilkan kesan alami dari alam dengan memberikan furniturefurniture yang ada dengan menggunakan material alami bahan batu guung sebagai aksen tambahan keindahan ruang dengan begitu dapat menjadikan ruangan akan terkesan nyaman dan merasakan kesan alaminya, serta juga menciptakan sirkulasi dengan terarah dan teratur dengan bahan alami dari batu gunung juga.

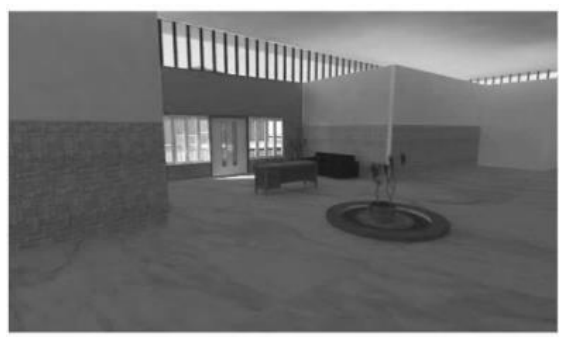

Gambar 6. Transformasi Ruang

\subsection{Desain Bentuk}

Penggunaan material yang didominasi oleh kaca pada bangunan sebagai ciri khas untuk mengidentitaskan suatu konsep yang diusung pada lahan tersebut. Dengan banyaknya penggunakan bahan-bahan yang $\mathrm{m}$

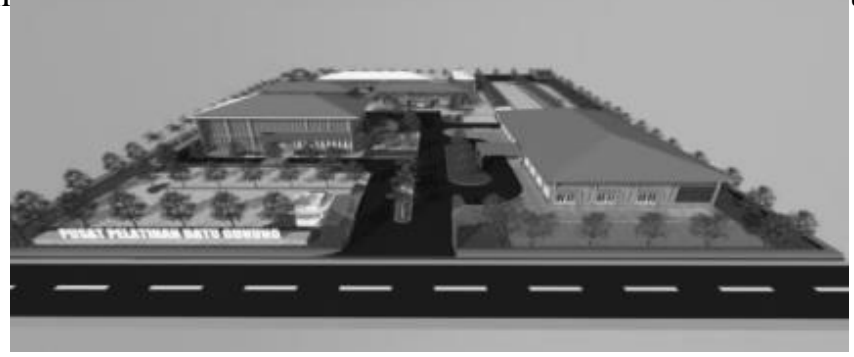




\section{Gambar 7. Desain Bentuk}

\subsection{Desain Ruang}

Fasilitas yang memerlukan ruang yang memberikan kenyamanan dan ketenangan bagi penggunanya, dengan mengedepankan pencahaayan dan sirkulasi udara yang baik dengan menambahkan bukaan-bukaan untuk menambah estetika tersendiri untuk bangunan tersebut.

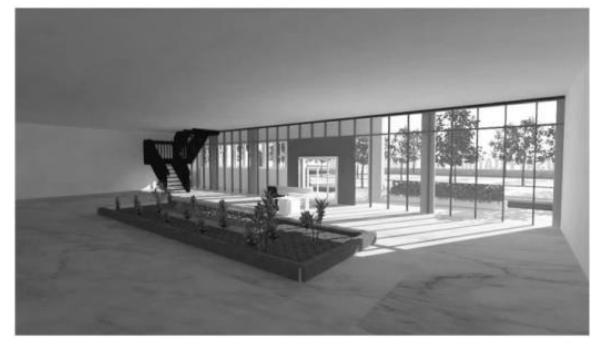

Gambar 8. Desain Ruang Penjualan

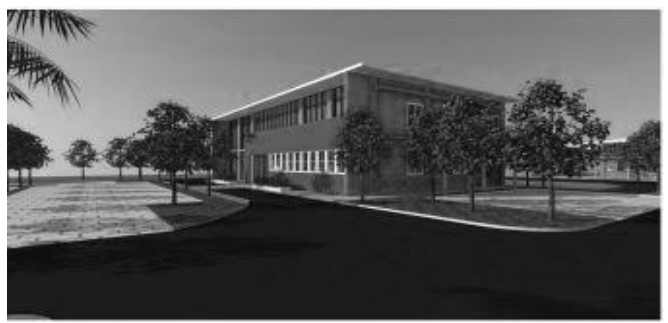

Gambar 9. Eksterior Ruang Penjualan

\subsection{Desain Struktur}

Desain struktur yang perlu diperhatikan seperti, pondasi, kolom struktur dan material atap yang digunakan. Maka penerapan bangunan ini menggunakan material beton dan batu kali pada sistem struktur dinding dan pondasi sebagai penumpu pada bangunan ini untuk menjadikan bangunan yang kokoh dan aman. Selain mengedepankan estetika desain fasad pada pusat pelatihan ini adalah untuk memfokuskan sistem struktur pada pusat pelatihan dan produksi guna untuk keamanan dan kenyamanan dalam jangka waktu panjang sehingga konsep berkelanjutan menjadi konsep utama dalam pusat pelatihan kerajinan ini
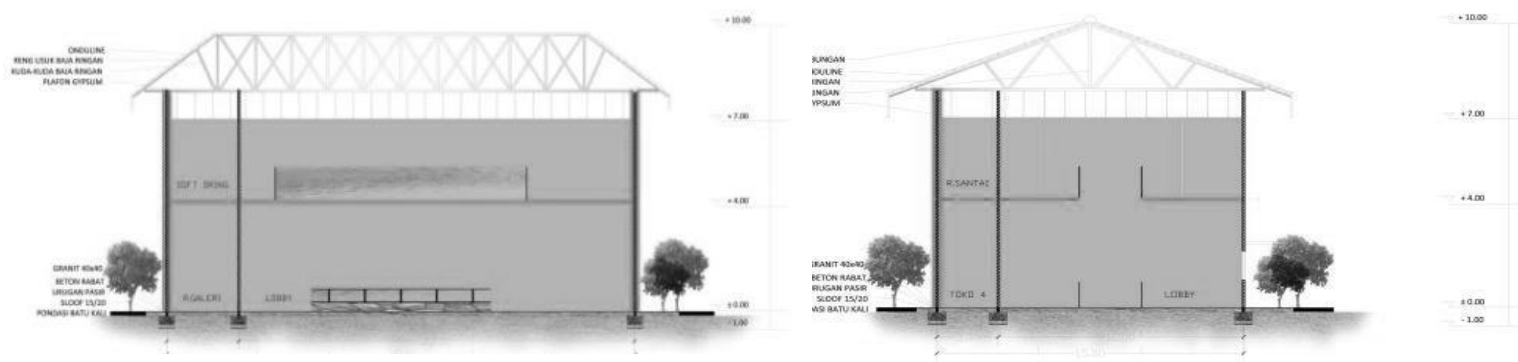

Gambar 10. Gambar Potongan Melintang (kiri) dan Potongan Membujur (kanan)

\section{Kesimpulan}


Dari pembahasan di atas dapat disimpulkan implementasi konsep sustainable architecture pada desain pusat pelatihan kerajinan batu gunung di Tulungagung adalah sebagai berikut:

a. Tatanan lahan yang digunakan menggunakan pola sirkulasi terarah dan teratur yang mana sirkulasi tersebut dinilai dapat memenuhi persyaratan dan kebutuhan ruang dengan penerapan arsitektur berkelanjutan serta memenuhi persyaratan ruang baik itu ruang dalam maupun luar yang ada di standar Arsiektur

b. Bentuk bangunan yang sederhana dengan material façade transparan yang ditata sedemikian rupa mengizinkan penghawaan untuk masuk ke dalam bangunan, dinilai mampu menjawab kebutuhan akan sirkulasi udara dan pencahayaan dalam bangunan. Penggunaan material tersebut juga mampu memperkuat karakter bangunan sebagai pusat pelatihan kerajinan batu gunung

c. Konsep ruang yang diigunakan adalah natural space yang memunculkan kesan nyaman dan tenang, di mana perhitungan besaran ruang telah dilakukan dengan memperhatikan kebutuhan serta keamanan pengguna bangunan baik itu pengunjung maupun pengrajin.

d. Untuk memenuhi kebutuhan dan fasilitas pengguna telah tercukupi dengan adanya ruang penunjang seperti gerai penjualan dan tempat pelatihan untuk batuan gunung

e. Ruang terbuka hijau yang tercukupi pada area lahan pusat pelatihan kerajinan batu gunung ini

\section{Referensi}

Adian, S. (2019, 11 23). penegertian kerajinan: Fungsi, Bahan, Jenis Jenis \& Contoh Kerajinan. Retrieved from www.salamadian.com: https://salamadian.com/pengertian-kerajinan/

Amin, M. N. (2019). Penerapan Prinsip Arsitektur Berkelanjutan pada Perencanaan Kampung Lestari. jurnal senTHong, 1.

Astuti, S. (2018). peningkatan kualitas ukm seni pahat melalui inovasi produk dan penggunaan pengawet kayu alami. ABDIMAS unmer malang, 2.

Baker, N., \& Koen, S. (2005). energy and environmental in architecture. new york: taylor \& francis group.

Dessler, G. (2005). Pearson Prentice. Human Resource management, 10.

Groat, L., \& Wang, D. (2002). Archiectural research Methods. Canada: John wiley \& sons,inc.

Handayani, K. (2018, 5 19). Ayo Menegenal Jenis Batuan. Retrieved from www.kabarhandayani.com: https://kabarhandayani.com/ayo-mengenal-jenis-batuan/

Laksmiyanti, D. P., Failasuf, H. H., \& Poppy, N. F. (2020). Desain Tanggap Iklim. Surabaya: cv pilar edukasi surabaya.

Maulida, S. (2016, 04 11). architecture \& urbanism. Retrieved from www.saptamaulida.com: https://saptamaulida.wordpress.com/2016/04/11/form-follow-function-or-function-followform/

Pujantara, R. (2014). Karakteristik Ruang Pada Rancangan Arsitektur. Jurnal Forum Bangunan, 1.

Raharjo, T., \& Suhartono, S. (2011). Seni Kriya dan Kerajinan. Yogyakarta. 